\title{
Direct, Real-Time Detection of Adenosine Triphosphate Release from Astrocytes in 3-Dimensional Culture Using an Integrated Electrochemical, Aptamer-Based Sensor
}

\author{
Mirelis Santos-Cancel ${ }^{\dagger}$, Laura W. Simpson ${ }^{\ddagger}$, Jennie B. Leach ${ }^{\ddagger}$, and Ryan J. White ${ }^{\dagger}$, \\ tDepartment of Chemistry, University of Cincinnati, Cincinnati, OH, USA \\ $\S$ Department of Electrical Engineering and Computer Science, University of Cincinnati, Cincinnati, \\ $\mathrm{OH}$, USA \\ $\ddagger$ Chemical, Biochemical and Environmental Engineering, University of Maryland Baltimore \\ County, Baltimore, MD, USA
}

\begin{abstract}
In this manuscript, we describe the development and application of electrochemical, aptamerbased (E-AB) sensors directly interfaced with astrocytes in three-dimensional (3D) cell culture to monitor stimulated release of adenosine triphosphate (ATP). The aptamer-based sensor couples specific detection of ATP, selective performance directly in cell culture media, and seconds time resolution using squarewave voltammetry for quantitative ATP-release measurements. More specifically, we demonstrate the ability to quantitatively monitor ATP release into the extracellular environment after stimulation by the addition of calcium $\left(\mathrm{Ca}^{2+}\right)$, ionomycin, and glutamate. The sensor response is confirmed to be specific to ATP and requires the presence of astrocytes in culture. For example, PC12 cells do not elicit a sensor response after stimulation with the same stimulants. In addition, we confirmed cell viability in the collagen matrix for all conditions tested. Our hydrogel-sensor interface offers the potential to study the release of small molecule messengers in 3D environments. Given the generality of electrochemical, aptamer-based sensors, and the demonstrated successful interfacing of sensors with tissue scaffold material, in the long term, we anticipate our sensors will be able to translate from in vitro to in vivo small molecule recordings.
\end{abstract}

\section{Graphical Abstract}

Corresponding author: Ryan J. White, ryan.white@uc.edu, phone number: +1 5135564369.

AUTHOR CONTRIBUTIONS

All authors contributed the writing and editing of the manuscript. MS-C was responsible for the design and completion of electrochemical experiments, viability assays, and data analysis. LWS was responsible for viability assays and statistical analysis of data.

Supporting Information

Supporting information includes viability studies, specificity studies, and regenerated E-AB sensor response and continuous E-AB sensor recordings of the E-AB sensor with and without stimulus (PDF). The Supporting Information is available free of charge on the ACS Publications website http://pubs.acs.org. 


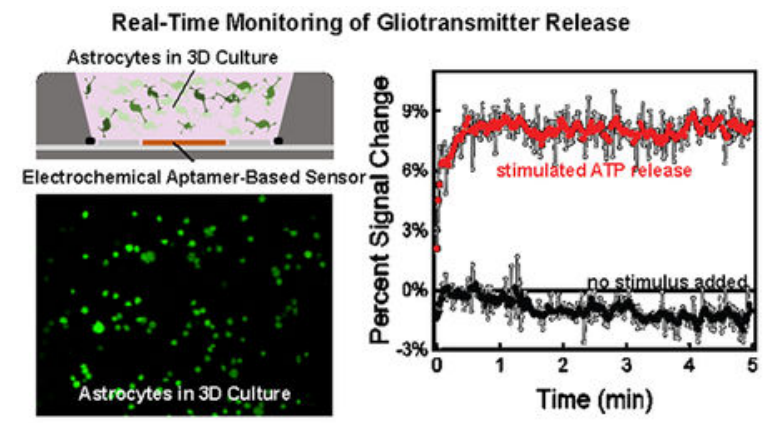

\section{Keywords}

aptamer-based sensor; ATP; astrocytes; gliotransmission; 3-D cell culture; electrochemistry

\section{INTRODUCTION}

Purinergic signaling from astrocytes through the release of gliotransmitters, including adenosine triphosphate (ATP), to the extracellular environment is integral in bidirectional communication in the brain. ${ }^{1,2,3}$ For example, defective ATP release has been associated with brain injuries, ${ }^{4}$ epileptic seizures,${ }^{5}$ Parkinson's and Alzheimer's Diseases, ${ }^{6}$ strokes and ischemia. ${ }^{7}$ While it is well established that astrocytes are important mediators of communication between neighboring neurons via the release of signaling molecules such as gliotransmitters, there is a shortfall of understanding the role glial signaling molecules and how this signaling is involved in brain circuitry. More specifically, the release of ATP from astrocytes is still considered controversial as reconciliation between what is observed in vitro versus in vivo has been elusive. ${ }^{1,2}$ Evidence suggests that in vitro studies of astrocytic gliotransmission processes, such as stimulation with pharmacological agents, results in the gliotransmitter release but there is a lack of specificity or physiological relevance, and current measurement challenges hinder translatability to in vivo studies. ${ }^{2}$ Despite multiple lines of evidence supporting gliotransmission as an essential component in the tripartite synapse regions of the brain, several reports have shown that gliotransmission does not occur under physiological conditions and is, rather, a pharmacological phenomenon. ${ }^{2}$ Most of the debate related to in vitro and in vivo gliotransmission processes relies on the inability of current analytical tools to study this process with the required sensitivity, specificity, and spatiotemporal resolution. ${ }^{1}$

To directly monitor and study the dynamics of purinergic signaling in brain processes, the sensing approach or analytical methodology needs to perform with high sensitivity in order to monitor low concentrations and specificity and selectivity to detect specific molecules in complex environments all combined with high spatial and temporal resolution. There are several examples of methods for ATP detection. Astrocytic ATP and other gliotransmitter biosensing have been achieved with multiple approaches including bioluminescence using the well-established luciferin-luciferase assay, ${ }^{8,9}$ microdialysis, ${ }^{10,11}$ and patch clamp or "sniffing." 12,13 These methods have provided valuable information about the role of ATP in brain processes, however, except for microdialysis, these methods have limited 
translatability to the in vivo setting. Electrochemical methods and electrochemical biosensors have been employed to the study of purinergic signaling in the brain. For example, Huang et al. reported electrochemical ATP recordings from a single astrocyte cell using changes in conductance of single-walled carbon nanotubes (SWNT) $1{ }^{14}$ Although this work is limited by non-specific interactions caused by other molecules released from astrocytes. Ross and Venton demonstrated the use of carbon fiber ultra-microelectrodes coupled with fast-scan cyclic voltammetry (FSCV) as a technique to monitor adenosine and ATP. ${ }^{15}$ While this method provides excellent spatiotemporal resolution required for monitoring fast dynamics in the brain, the electrochemical response exhibited enhanced sensitivity towards adenosine over ATP. ${ }^{15,16}$ Furthermore, this method relies on direct oxidation of these analytes at the electrode surface and the method is thus prone to interferents from other electroactive species in solution (e.g., $\mathrm{H}_{2} \mathrm{O}_{2}$ ).

Enzyme-based amperometric biosensors offer an alternative strategy for the sensitive and rapid (ms) detection of ATP. Llaudet et al. reports on the development of an amperometric biosensor based on platinum (Pt) microelectrode-coupled enzymatic cascades to detect ATP and adenosine. ${ }^{17}$ This amperometric sensor showed good temporal and spatial resolution with a sensitivity to ATP within $\mathrm{nM}$ levels. ${ }^{17}$ The signaling mechanism relies on enzymatic cascade comprising glycerol kinase and glycerol-3-phosphate oxidase which generates $\mathrm{H}_{2} \mathrm{O}_{2}$ in an ATP-concentration dependent manner. The cascade also requires $\mathrm{O}_{2}$ and glycerol. While this example demonstrates good analytical performance in physiological conditions and biological tissue, enzyme-based amperometric biosensors are generally prone to experimental interferences caused by changes in substrate or cofactor (e.g., glycerol/ $\mathrm{O}_{2}$ ) levels or secondary products of enzymatic or catalytic reactions. ${ }^{18}$

Structure-switching electrochemical, aptamer-based (E-AB) sensors represent an alternative method suitable for real-time and specific quantification of molecular analytes. ${ }^{19,20}$ Aptamers are short deoxyribonucleic acid (DNA) or ribonucleic acid (RNA) sequences selected in vitro via systematic evolution of ligands by exponential enrichment (SELEX) to bind to a target analyte with high specificity. ${ }^{21}$ The unique combination of aptamers and electrochemistry as a signal transduction methodology have been documented for point-ofcare (POC) and clinical applications. ${ }^{22}$ E-AB sensors, first described by Plaxco and coworkers, report target-induced conformational changes of the redox active-labeled aptamer. ${ }^{23}$ Several reports confirmed the suitability of E-AB sensors to detect small neuroactive molecules specifically. White, et al., for example, reported the use of an E-AB with enhanced sensitivity for ATP by rationally engineering the primary sequence determined by Huizenga et al. ${ }^{24,25}$ Ferapontova and coworkers demonstrated dopamine detection with an electrochemical biosensor employing an RNA aptamer sequence. ${ }^{26,27}$ These examples support that $\mathrm{E}-\mathrm{AB}$ sensors are poised as a suitable methodology for the detection and quantification of small neuroactive molecules. Moreover, the reagentless and regenerative nature ${ }^{28}$ of $\mathrm{E}-\mathrm{AB}$ sensors combined with the use of interrogation methods such as square wave voltammetry (SWV) and the recently introduced intermittent pulse amperometry (IPA) ${ }^{29,30}$ with small size electrodes ${ }^{31}$ offer potential electrochemical recordings of small molecule targets with high specificity, $\mathrm{ms}-\mathrm{s}$ temporal resolution and $\mu \mathrm{m}$ spatial resolution. Other advantages of using E-AB sensors include several strategies that can be employed to enhance the analytical performance of the sensor. For example, the 
nucleic acid structure can be rationally engineered to maximize the magnitude of the signal change (i.e., sensitivity and limit of detection). ${ }^{30}$ The dynamic range of aptamer sensors can also be optimized or tuned using mixed monolayers of aptamers for the same target but with different affinities. ${ }^{32}$ The analytical performance can also be tuned via the method of electrochemical interrogation. ${ }^{33,34}$ Furthermore, nanostructuring of the electrode surface can lead to enhanced sensitivity. ${ }^{31}$

In addition to providing detection of important small molecule targets, electrochemical aptamer-based biosensing approaches have also been used for monitoring large chemokine release from a population of cells in two-dimensional culture. For example, Liu et al. demonstrated in vitro electrochemical aptamer-based sensing strategies for the simultaneous detection of tumor necrosis factor- $a$ (TNF- $a$ ) and interferon-gamma (IFN- $\gamma$ ) release from human CD4 T-cells and U937 monocytic cells via a dual aptamer system. ${ }^{35,36}$ In another example, Matharu et al. showed the integration of an aptasensor with microfluidics for the quantification of transforming growth factor-beta 1 (TGF- $\beta 1$ ) release from hepatic stellate cells. $^{37}$

In this paper, we describe the development and application of an E-AB sensor for the direct detection of ATP release from a population of astrocytes. To achieve this, we interfaced the sensor with a three-dimensional (3D) hydrogel-based cell culture for the real-time and continuous detection of ATP release from astrocytes. This interface is based in on our previous reports of using hydrogels for improved E-AB sensor stability and performance in complex media. ${ }^{38,39}$ Moreover, this approach provides several advantages such as the wellestablished microenvironment for astrocytes when compared with 2D cultures reported elsewhere. ${ }^{40,41}$ Using the collagen-sensor interface, we reproducibly recorded continuous, real-time (s) ATP release measurements from astrocytes after stimulation via extracellular calcium $\left(\mathrm{Ca}^{2+}\right)$, ionomycin, and glutamate. In addition, we included the use of an exocytosis inhibitor which resulted in a reduction in the ATP signal after stimulation. We also demonstrate that we do not observe appreciable levels of ATP when PC12 cells are cultured and stimulated in the same setup. Our approach proposes a new way to monitor small molecules related to the chemistry of the brain, or other cellular communication processes, in vitro with possible translation to in vivo samples. While there have been other examples of real-time ATP detection in biological tissue as described above, ${ }^{17}$ the use of E-AB offers a reagentless approach less prone to interferences from secondary products of catalytic processes or the presence of other redox species. ${ }^{18}$ Given the generality of the aptamerbased sensing approach and the generality of hydrogel interfaces ${ }^{38,39}$ our interfaced sensors can be applied to a wide range of small molecule release from a variety of cell types.

\section{RESULTS AND DISCUSSION}

\section{E-AB sensors detect ATP when interfaced with a collagen tissue scaffold}

In this report, we utilize collagen I hydrogels as scaffolds to create an interface between 3D astrocyte cell culture and an E-AB sensor to study gliotransmitter release. Balasubramanian et al. and Placone, et al. demonstrated that collagen hydrogels provide an excellent 3D microenvironment for astrocyte cell culture which promotes morphological heterogeneity similar to what is observed in vivo in comparison to cells cultured in $2 \mathrm{D} .{ }^{40,41}$ More 
specifically, astrocytes cultured in two dimensions typically remain in the round state.

Conversely, in 3D culture, the astrocytes transition from round to more bipolar and stellate morphologies. These observed morphologies are more indicative of normal development in contrast to round morphologies which are more indicative of injured cells. The use of 3D cell culture is a generalizable approach and have been utilized for culture of other cell lines including PC12 and Schwann cells. ${ }^{42}$ In general, hydrogels offer multiple and diverse uses in regenerative medicine, ${ }^{43}$ drug delivery, ${ }^{44,45}$ small molecule encapsulation, ${ }^{39}$ and $3 \mathrm{D}$ cell culture. ${ }^{46}$ E-AB sensors can be successfully interfaced with hydrogels for improved stability and performance, and thus an advantage here is that the described sensor interfaced with this environment enables measure of ATP release from more in vivo like cells. We previously reported two examples of hydrogel-interfaced sensors including the use of polyacrylamide ${ }^{38}$ and collagen hydrogels. ${ }^{39}$ In the latter report, we demonstrated the use of collagen-covered electrochemical RNA-aptamer-based sensors to monitor aminoglycoside antibiotics in untreated, undiluted complex medium (serum). ${ }^{39}$ The integration of the collagen film protects the sensor surface from nuclease activity while still allowing quantitative determination of target analyte concentrations. ${ }^{39}$

Similar to previous examples, ${ }^{38,39}$ we validated the electrochemical response and sensor performance of the ATP E-AB sensor interfaced with a collagen hydrogel with optimal cell culture conditions and in cell culture media (84\% DMEM-high glucose, 15\% FBS, and 1\% 10,000 U/mL Pen/Strep) (Figure 1 left and SI Figure 1). The interfaced E-AB sensor responds quantitatively to the addition of ATP directly in cell culture media exhibiting a maximum signal gain of $\sim 30 \%$ under saturating conditions ( $1 \mathrm{mM} \mathrm{ATP}$ ) (Figure 1 left). We performed calibration titrations by quantifying sensor signal interfaced with a $0.8 \mathrm{mg} / \mathrm{mL}$ collagen I film by reporting sensor percent signal change which is the change in signal with ATP (SWV peak current) normalized to the SWV peak current observed without ATP. The newly interfaced sensor responded quantitatively to changes in ATP in cell culture media exhibiting a binding affinity $\left(\mathrm{K}_{\mathrm{D}}\right) \sim 17 \pm 3 \mu \mathrm{M}$ (Figure 1 right). The sensor performance is comparable to that of uncoated sensors in buffer (tris buffer, $\mathrm{pH} \sim 7.4$ ). ${ }^{24}$ Furthermore, the sensor exhibited a dynamic range between $1-10 \mu \mathrm{M}$ with the lowest limit of detection (LOD) and quantification (LOQ) of 2.5 and $8.2 \mu \mathrm{M}$, respectively. True to this type of sensor, the sensor can be regenerated multiple times after coating demonstrating reversibility (SI Figure 2).

\section{E-AB sensor interfaced with 3D astrocyte cell culture to quantify purinergic signaling through ATP release from astrocytes}

To accomplish our aim to obtain in vitro, real-time recordings of ATP release we challenged the E-AB astrocyte $3 \mathrm{D}$ cell culture to an injection of $\mathrm{Ca}^{2+}$ to the extracellular environment. In contrast with neurons, astrocytes are non-electrically excitable cells. Taking advantage of the endogenous excitability of astrocytes caused by increasing extracellular $\mathrm{Ca}^{2+}$ levels, we used this mechanism to trigger ATP release. Astrocyte gliotransmitter release occurs as a result of changes to cytoplasmic $\mathrm{Ca}^{2+}$ levels. ${ }^{47}$ Moreover, changes in intracellular calcium $\left(\left[\mathrm{Ca}^{2+}\right]_{\mathrm{i}}\right)$ induced by extracellular $\mathrm{Ca}^{2+}$ signaling represents one of the hypotheses for ATP release from astrocytes. ${ }^{9}$ 
The integrated sensor (Scheme 1) exhibits a relatively stable baseline in the absence and presence of astrocytes. More specifically, we performed control experiments in which continuous SWV recordings were taken of coated sensors in cell culture media without astrocytes. The E-AB sensors were stable to this interrogation as indicated by a stable signal over a time course of 5 min (SI Figure 3). A stable baseline is also observed when astrocyte cells are present. To test this, we interfaced a sensor with a densely populated collagen film $\left(1.1 \times 10^{5}\right.$ cells $\left./ \mathrm{mL}\right)$. The sensor exhibited no increase in a signal indicating that extracellular ATP levels remained constant and the sensor was stable when no stimulus is added (SI Figure 3 left). Collagen-covered E-AB sensors did, however, demonstrate a minor, but steady decrease in SWV peak current over the time course of the recordings (SI Figure 3 right). This electrochemical signal decay associated with the signal drift has been reported elsewhere. ${ }^{20,48}$ Fluorescence imagining studies confirmed astrocytic cell viability when encapsulated in a $0.8 \mathrm{mg} / \mathrm{mL}$ collagen I hydrogel. More specifically, astrocytes show a $94 \%$ viability under these experimental conditions (Figure 2).

E-AB sensors interfaced with astrocytes in 3D culture exhibited quantitative signal change after $\mathrm{Ca}^{2+}$ was added to induce purinergic signaling through ATP release. Also, the magnitude and rate of change of the signal correlated with the number of cells in the collagen gel. We measured the $\mathrm{Ca}^{2+}$-triggered response from three different and independent astrocyte cell populations cultured in a collagen matrix above a sensor surface (Figure 3 left). The sensors were interfaced with collagen-astrocyte mixtures with variable cell populations ranging from $0.2 \times 10^{5}$ to $1.1 \times 10^{5}$ cells $/ \mathrm{mL}$. $\mathrm{Ca}^{2+}$ - triggered ATP release was achieved by introducing $\mathrm{CaCl}_{2}$ to the extracellular environment to reach a final concentration of $10 \mathrm{mM}$ while recording SWV signal with repetitive scans. The sensors exhibited quantitative signal changes ranging from $11 \%$ in the highest cell population to $6 \%$ for the lowest (Figure 3 left), which correlated to ATP concentrations of $7.0 \pm 0.7 \mu \mathrm{M}, 6 \pm 2$ $\mu \mathrm{M}$, and $3.3 \pm 0.7 \mu \mathrm{M}$ for $1.1,0.7$ and $0.2 \times 10^{5}$ cells $/ \mathrm{mL}$. As a control measurement, the signal is relatively stable when no stimulus is added $\left(0.7 \times 10^{5}\right.$ cells $/ \mathrm{mL}$, Figure 3 left $)$. All concentrations and standard deviations were acquired using three independently fabricated E-AB sensor $3 \mathrm{D}$ astrocyte culture interfaces. In addition to the magnitude of signal change being related to the cell population, the rate of ATP concentration change is dependent on cell density. For example, the rise time for ATP concentration change in the lowest cell density is $17 \pm 1 \mathrm{~min}^{-1}\left(0.2 \times 10^{5}\right.$ cells $\left./ \mathrm{mL}\right)$ whereas, the rate of increase is $19 \pm 3 \mathrm{~min}^{-1}$ and $25 \pm 2 \mathrm{~min}^{-1}$ for 0.7 and $1.1 \times 10^{5}$ cells $/ \mathrm{mL}$ cell densities respectively (Figure 3 right).

As one method to confirm that the observed change in sensor signal is related to ATP release from astrocytes, we disrupted the $\mathrm{Ca}^{2+}$-dependent exocytotic release mechanism. The use of intracellular calcium $\left(\left[\mathrm{Ca}^{2+}\right]_{\mathrm{i}}\right)$ chelating agent should significantly diminish ATP release after the addition of stimulus. ${ }^{49}$ We employed the chelator BAPTA-AM in the 3D astrocyte cell culture as a negative control to disrupt intracellular $\mathrm{Ca}^{2+}$ activity and control the proposed $\left(\left[\mathrm{Ca}^{2+}\right]_{\mathrm{i}}\right)$-dependent process of exocytosis. ${ }^{8}$ Using a cell population of $0.7 \times 10^{5}$ cells $/ \mathrm{mL}$ treated with $0.5 \mu \mathrm{M}$ BAPTA-AM for $1.5 \mathrm{hr}$ prior electrochemical measurements, the ATP sensor exhibited a modest $\sim 3 \%$ signal change after the addition of $10 \mathrm{mM} \mathrm{CaCl}_{2}$ to trigger ATP release (Figure 4 left). The observed signal change is significantly lower than the electrochemical signal increase observed when using untreated cells ( 7\%) under similar stimulating conditions. The signal change observed with the BAPTA-AM treated cells 
corresponds to a $\sim 1.3 \pm 0.2 \mu \mathrm{M}$ ATP concentration in the extracellular matrix contrasted to the $4.0 \pm 0.3 \mu \mathrm{M}$ observed using a similar cell density without the addition of BAPTA-AM. Consistent with previous findings, $, 850,51$ the reduction in observed extracellular ATP concentration confirms successful inhibition on $\mathrm{Ca}^{2+}$-triggered ATP release from astrocyte cells, however not a total blockade (Figure 4 right).

In addition to $\mathrm{Ca}^{2+}$-triggered release of ATP, the $\mathrm{E}-\mathrm{AB}$ sensors quantitatively monitor ATP release triggered by the neuroactive molecule glutamate and ionomycin. ${ }^{52,53}$ Several reports have demonstrated that the increase in extracellular $\mathrm{Ca}^{2+}$ levels induces $\left(\left[\mathrm{Ca}^{2+}\right]_{\mathrm{i}}\right)$ waves that trigger the release of glutamate ${ }^{54}$ and $\mathrm{ATP}^{9}$ among other gliotransmitters. Moreover, Pangršič et al. confirmed ATP vesicular secretion from astrocytes upon endogenous stimulation via glutamate using total internal reflection fluorescence (TIRF). ${ }^{12}$ The introduction of glutamate to a final extracellular concentration of $1 \mathrm{mM}$ to the cell culture media caused an increase in sensor signal change $(\sim 14 \%)$ in an astrocyte cell culture with $0.7 \times 10^{5}$ cells $/ \mathrm{mL}$. This signal change corresponds to an increase of extracellular ATP to 9 $\pm 1 \mu \mathrm{M}$ (Figure 5 left). Of note, while the incorporation of glutamate appears to trigger ATP release at a higher level than $\mathrm{Ca}^{2+}$, the rate of this increase is slower than what is observed with $\mathrm{Ca}^{2+}\left(8.2 \pm 0.6 \mathrm{~min}^{-1}\right.$ and $19 \pm 3 \mathrm{~min}^{-1}$, for glutamate and $\mathrm{Ca}^{2+}$ respectively (Figure 5 right). Likewise, the addition of a final concentration of $1 \mu \mathrm{M}$ ionomycin to the cell culture media induced a rapid $\left(11 \pm 3 \mathrm{~min}^{-1}\right)$ response. The rapidity of ionomycin-triggered exocytosis over, for example, $\mathrm{Ca}^{2+}$ or glutamate, has been reported elsewhere including the release of ATP from astrocyte cells, ${ }^{12}$ dopamine from PC12 cells, ${ }^{55}$ and tumor necrosis factor-a (TNF-a) and interferon-gamma (IFN- $\gamma$ ) release from human CD4 T-cells and U937 monocytic cells. ${ }^{35}$ This fast response reached a maximum signal change from the E$\mathrm{AB}$ sensor to $\sim 12 \%$ using a cell population density of $0.7 \times 10^{5}$ cells $/ \mathrm{mL}$ (Figure 5 left and right).

Under all conditions tested, $\mathrm{Ca}^{2+}$ addition, with and without BAPTA, ionomycin addition, and glutamate addition, the astrocytes remained viable. Briefly, The number of viable (green fluorescent) and dead (red fluorescent) cells remained constant ( $\geq 90 \%$ viability) after the various stimuli with a p-value of 0.945 indicating there is no significant difference between the cell viabilities with stimulus and the control (Figure 6 left). We further explored the effect of BAPTA-AM incorporation on cells. Fluorescence imaging (Figure 6 left) shows that the intracellular calcium chelator appears to cause minimal disruptions to astrocytes with viability $\geq 90 \%$ (Figure 6 right) compatible with measurements acquired prior treatment.

\section{The E-AB sensor provides a platform to detect ATP with high specificity}

Astrocytes achieve communication through the release of gliotransmitters including ATP, glutamate, D-serine among others. ${ }^{56}$ Moreover, purinergic signaling through ATP release is one of the multiple pathways that assure communication between astrocytes and neurons in the tripartite synapse. ${ }^{57,58}$ Analytical tools to measure any brain process, including gliotransmission, need to provide high specificity to discriminate between co-released molecules during communication events. To confirm the measure of ATP using our sensors, we benchmarked extracellular ATP measurements using a luciferin/luciferase 
bioluminescence assay. This method has been successfully used to sensitively detect ATP over other adenosine compounds (adenosine triphosphate (ADP), adenosine monophosphate (AMP), and adenosine) with high specificity. ${ }^{9,59}$ Moreover, this assay has been reported to detect intracellular ATP levels on cells cultured in hydrogels. ${ }^{60,61}$ Relative luminescence units (RLU) measurements acquired after the incorporation of the variously-used stimuli confirm ATP release from astrocyte cells. Briefly, $0.7 \times 10^{5}$ astrocyte cells $/ \mathrm{mL}$ encapsulated in collagen were incubated with an equimolar concentration of D-luciferin and the firefly enzyme luciferase $(0.2 \mathrm{mg} / \mathrm{mL})$ in the presence of $5 \mathrm{mM} \mathrm{MgCl}_{2}$ and individually cultured and exposed to individual stimuli for $5 \mathrm{~min}$. The addition of $10 \mathrm{mM} \mathrm{CaCl}_{2}, 1 \mathrm{mM}$ glutamate, and $0.5 \mu \mathrm{M}$ ionomycin all increased luminescence signal when compared to control measurements when no stimulus is added to cell culture media. The observed changes in luminescence correlate well with electrochemical recordings which demonstrated that the incorporation of glutamate is more efficient at triggering ATP release when compared with $\mathrm{Ca}^{2+}$ and ionomycin (Figure 7). The luminescence assay also confirmed treatment with BAPTA-AM $(0.5 \mu \mathrm{M}$ for $1.5 \mathrm{hr})$ significantly reduced ATP release from astrocytes after stimulation with $\mathrm{Ca}^{2+}$.

\section{The E-AB sensor shows high specificity to ATP over other important neuroactive molecules}

To test the specificity of our assay to ATP release, we employed the methodology with cultured PC12 cells in the same collagen type I $(0.8 \mathrm{mg} / \mathrm{mL})$ matrix. Fluorescence imaging studies demonstrate that $\mathrm{PC} 12$ cells remain viable under experimental conditions (Figure 8 bottom right). PC12 cells have been extensively studied, and their exocytotic response to multiple stimuli characterized through the quantification of catecholamine (dopamine and norepinephrine) release. ${ }^{62}$ The PC12 cells were subjected to the same stimuli used for testing the astrocyte cells, all of which are proven to be effective in triggering exocytotic processes in PC12 cells. ${ }^{55,62,63}$ The E-AB sensor exhibited baseline level signals after $\mathrm{Ca}^{2+}$, glutamate, and ionomycin stimuli was added to PC12 cells $\left(0.7 \times 10^{5}\right.$ astrocytes $/ \mathrm{mL}$; Figure 8 top left, right and bottom left, respectively) that our sensors do not respond to catecholamines and that PC12 cells are not releasing significant amounts of ATP. The E-AB sensor did not respond to the release of catecholamines from PC12 cells (SI Figure 4). Reports do suggest that PC12 cells co-release purines (ATP, ADP, AMP, and adenosine) using the same secretory mechanism. ${ }^{64}$ While it is accepted that PC12 cells contain purinergic receptors located at the plasma membrane ${ }^{65}$, the ratio of catecholamine (dopamine) to purine release has been reported to be 9:5. ${ }^{66}$ As such, we expect that purine release from PC12 cells results in an ATP concentration that is outside the dynamic range of the current $\mathrm{E}-\mathrm{AB}$ sensor.

\section{CONCLUSIONS}

In this manuscript, we demonstrated the use of an interface between E-AB sensors with 3D cell culture to obtain in vitro recordings of ATP release from astrocytes. The sensor responds with seconds resolution to changes in extracellular ATP levels $(\mu \mathrm{M})$ provoked by various stimuli including $\mathrm{Ca}^{2+}$, glutamate, and ionomycin. Conversely, if an exocytosis inhibitor is added to the cell culture media, the release of ATP, and thus sensor response, is diminished. 
The response and ATP levels are quantitatively related to the cell population density as well as the type of stimuli provided. The presence of ATP in the extracellular environment is confirmed using the well-established luciferin/luciferase assay. Our methodology provides a means for the direct detection of ATP release using sensor response. Ultimately, we believe this work represents a new reagentless platform for studying the dynamics of molecular target release from cells in 3D culture as it relies on the generic signaling mechanism of folding-based electrochemical sensors employing nucleic acid aptamer recognition elements. Given the generality of both the E-AB sensor approach and the use of 3D cell culture, we anticipate that this method can be applied to a wide range of cell types and target analytes.

\section{METHODS}

\section{Electrochemical, aptamer-based sensor materials}

The "destabilized" ATP aptamer (5' - CTGGGGGAGTATTGCGGAGGAAA-3') oligonucleotide sequence ${ }^{24}$ was purified using dual HPLC (Biosearch Technologies, CA) and used as received. Tris-2-carboxyethyl-phosphine (TCEP), ferrocenemethanol (FcMeOH), 6-mercapto-1-hexanol (99\%), Trizma (tris) base (2-amino- 2(hydroxymethyl)-1,3-propanediol, magnesium chloride $\left(\mathrm{MgCl}_{2}\right)$, sulfuric acid $\left(\mathrm{H}_{2} \mathrm{SO}_{4}\right)$, potassium chloride $(\mathrm{KCl})$, hydrogen peroxide $\left(\mathrm{H}_{2} \mathrm{O}_{2}\right)$, hydrochloric acid $(\mathrm{HCl})$ sodium chloride ( $\mathrm{NaCl}$ ), adenosine triphosphate (ATP), dopamine hydrochloride (99\%) (Alfa Aesar), dimethyl sulfoxide (DMSO), and 10x Tris-EDTA were used as received from Sigma- Aldrich. All solutions were prepared using autoclaved, ultrapure water $(18.0 \mathrm{M} \Omega \mathrm{cm}$ at $25^{\circ} \mathrm{C}$ ) using a Biopak Polisher Millipore ultra purification system (Millipore, Billerica, $\mathrm{MA})$.

\section{Rat primary cortical astrocytes and PC12 cells culture materials}

Fetal bovine serum (FBS), $7.5 \%$ sodium bicarbonate solution $\left(\mathrm{NaHCO}_{3}\right)$, cell culture grade water, 10,000 U/mL Penicillin/Streptomycin (Pen/Strep), 10× Dulbecco's Modified Eagle's Medium- low glucose (DMEM), PC12 cells, and ionomycin from Streptomyces conglobatus were used as acquired from Sigma. Sodium L-glutamate monohydrate and 1,2-Bis(2aminophenoxy)ethane- $N, N, N, N$-tetraacetic acid tetrakis(acetoxymethyl ester) (BAPTA$\mathrm{AM}$ ), Heat-Inactivated (HI) Horse Serum were acquired and used as received from Thermo Fisher. Rat primary cortical astrocytes were received from Invitrogen. Dulbecco's Modified Eagle Medium (DMEM) (+4.00 mM L-Glutamine, $+450 \mathrm{mg} / \mathrm{L}$ glucose, -sodium pyruvate) and $10 \times$ PBS buffer (Hyclone); trypan blue (0.4\%), collagen I from rat tail, and $0.25 \%$ trypsin (1 $\times$ ) (Gibco); Live/Dead Cell Imagining Kit for mammalian cells (Invitrogen) were used as received. RPMI-1640 (high glucose, with L-glutamine, with HEPES) was obtained from ATCC.

\section{Rat primary cortical astrocytes and PC12 establishment and culture}

Rat primary cortical astrocytes were prepared as described in the protocol provided by Invitrogen. Briefly, astrocytes were thawed quickly at $37^{\circ} \mathrm{C}$ and then transferred to a previously-rinsed Falcon tube containing fresh cell culture media composed of $84 \%$ DMEM- high glucose, $14 \%$ FBS, and 1\% 10,000 U/mL Pen Strep. The cell suspension was centrifuged at $30 \mathrm{~g} \times 10 \mathrm{~min}$ at room temperature (RT) to pellet, then seeded in a $75-\mathrm{cm}^{2}$ 
flask and grown at $37^{\circ} \mathrm{C}$ in a $5 \% \mathrm{CO}_{2} / 95 \%$ humidity incubator for 5-7 days until $90-95 \%$ confluency. Astrocytes were grown to $90-95 \%$ confluency at $37^{\circ} \mathrm{C}$ in a $5 \% \mathrm{CO}_{2} / 95 \%$ environment for 5-7 days in a $75 \mathrm{~cm}^{2}$ flask. PC12 cells were prepared in cell culture media containing 84\% RPMI-1640 media (ATCC), 10\% HI horse serum, 5\% FBS, and 1\% 10,000 $\mathrm{U} / \mathrm{mL}$ Pen/Strep. In a previous step, cells were thawed quickly at $37^{\circ} \mathrm{C}$ and transferred to a previously-rinsed Falcon tube containing fresh cell culture media. Cells were centrifuged at $30 \mathrm{~g} \times 10 \mathrm{~min}$ at RT to pellet, then seeded in a $75-\mathrm{cm}^{2}$ flask and grown at $37^{\circ} \mathrm{C}$ in a $5 \%$ $\mathrm{CO}_{2} / 95 \%$ incubator for 5-7 days until 90-95\% confluency. Both astrocytic and PC12 cell culture media was renewed every $2-3$ days.

\section{E-AB sensor preparation}

E-AB sensors were prepared on a thin-film electrode containing one 1-mm-diameter gold $(\mathrm{Au})$ working electrode, one platinum counter electrode $(\mathrm{CE})$, and one platinum pseudoreference electrode (PRE) acquired from Micrux (ED-SE1- AuPt from Micrux Fluidic, Oviedo, Spain). Electrodes were hand polished in an aluminum oxide slurry (Buehler) for 2 min using a disposable cotton swab, followed by piranha cleaning for 1 min. Caution: Piranha solution reacts violently with most organic materials and must be handled with extreme care. Electrodes were further electrochemically cleaned through reductive desorption in a $0.5 \mathrm{M} \mathrm{NaOH}$ solution as previously described. ${ }^{30}$ Once cleaned, thin-film electrodes were incubated in a $400 \mathrm{nM}$ destabilized ATP aptamer solution in sterile tris buffer (20 mM Trizma base, $100 \mathrm{mM} \mathrm{NaCl}$, and $5 \mathrm{mM} \mathrm{MgCl}_{2}$ ) pH 7.4 for $1 \mathrm{~h}$. The destabilized ATP aptamer was previously incubated with $2 \mu \mathrm{L}$ of $100 \mathrm{mM}$ TCEP for $1 \mathrm{~h}$ to reduce the $5^{\prime}$ - disulfide bond. This incubation was followed by the addition of the diluent 6 mercapto-1-hexanol (30 mM) for $1 \mathrm{hr}$ to passivate the surface. Sensors were equilibrated in tris buffer (RT) for $1 \mathrm{~h}$ before experiments.

\section{D cell culture interfaced with E-AB sensor}

Astrocyte cells (90-95\% confluency level) were trypsinized for $10 \mathrm{~min}$ at $37^{\circ} \mathrm{C}$ to dissociate adherent proteins on the plate surface. Cells were centrifuged ( $30 \mathrm{~g} \times 10 \mathrm{~min})$, followed by the disposal of supernatant media, and suspended in fresh cell culture media in a previously rinsed $15 \mathrm{~mL}$ centrifuge tube. Trypan blue staining was used to count live cells on a hemocytometer. Astrocytes were encapsulated in 3D collagen gels as previously described by Leach and Powell with a few modifications. ${ }^{67}$ Briefly, a solution of $3 \mathrm{mg} / \mathrm{mL}$ collagen I from rat tail was mixed with 10× DMEM- low glucose, $7.5 \% \mathrm{NaHCO}_{3}, 10 \times \mathrm{PBS}$ buffer and water to reach final a final concentration of $0.8 \mathrm{mg} / \mathrm{mL}$ collagen, $10 \%$ DMEM- low glucose, $15 \% \mathrm{NaHCO}_{3}, 0.1 \times$ PBS in the gel. All solutions were kept in ice-cold conditions prior use. Different aliquots of cells suspended in cell culture media were added to achieve the desired cell density. The cold cell-collagen solution was then dispensed on top of the fabricated ATP E-AB sensor, which was placed on a commercial aluminum base (AIO Drop Cell-base) with a poly(methyl methacrylate) (PMMA) cover (AIO Cell Add-On Batch Cell PMMA-2.0) (Micrux Technologies, Oviedo, Spain) and allowed to polymerize for $30 \mathrm{~min}$ at (RT). The interfaced collagen-hydrogel sensor was then equilibrated in previously-warmed cell culture media at RT for $1 \mathrm{hr}$. Equilibration of the array was recorded using SWV every 10 min until the electrochemical signal remained constant. Sensors with collagen-encapsulated PC12 cells were prepared similarly as for the astrocyte cells. 


\section{Electrochemical measurements}

All electrochemical measurements were performed using a CH Instruments 620D

Electrochemical Workstation (CH Instruments, Austin, TX) in a three-electrode configuration. Continuous square wave voltammograms were acquired using a pulse amplitude of $25 \mathrm{mV}$ with a frequency equivalent to $400 \mathrm{~Hz}$ and a step width of $1 \mathrm{mV}$. Individual measurements were acquired equivalently for all SWV measurements.

\section{Viability assays}

Astrocyte cells were encapsulated in collagen hydrogels as described above, except that the cell-collagen solution was dispensed onto a CultureWell chambered coverglass (Electron Microscopy Sciences) and allowed to polymerize at RT for $35 \mathrm{~min}$. Once polymerized, the hydrogels were equilibrated in previously-warmed cell culture media at RT for $1 \mathrm{hr}$. A LIVE/DEAD cell imaging kit (ex/em 488/570) (R37601, ThermoFisher) was used according to the manufacturer's instructions and incubated with cells (RT) for $15 \mathrm{~min}$. The cells were imaged at ambient temperature $\left(\sim 25^{\circ} \mathrm{C}\right)$ with a $20 \times$ oil objective on a scanning confocal microscope (Leica SP5, Buffalo Grove, IL) capturing green-fluorescing calcein in live cells and red-fluorescing ethidium homodimer- 1 in dead cells. Each image analyzed was a compressed set of $10 \mathrm{z}$-stack images of the collagen hydrogel spanning up to $100 \mu \mathrm{m}$ in total z-thickness. Cell viability was tested at experimental conditions $\left(5 \mathrm{mM} \mathrm{CaCl}_{2}, 1 \mu \mathrm{M}\right.$ ionomycin, $1 \mathrm{mM}$ glutamate, and $5 \mathrm{mM} \mathrm{CaCl}_{2}$ added to $0.5 \mu \mathrm{M}$ BAPTA incorporated hydrogels) > 1 min after inoculation. Three experiments were conducted containing 3 hydrogels per condition and 2 compressed images per hydrogel. A one-way ANOVA was carried out with a p-value below 0.05 indicating a significant difference between the population means.

\section{Bioluminescence Assay for ATP}

Astrocyte cells were encapsulated in collagen hydrogels as described above, except that the cell-collagen solution was dispensed ( $50 \mu \mathrm{L})$ into a 96-well plate (Corning) with a cell density of $0.7 \times 10^{5}$ cells $/ \mathrm{mL}$ in each gel and allowed to polymerize for 30 min at RT. Samples were equilibrated in warm cell culture media supplemented with $5 \mathrm{mM} \mathrm{MgCl} 2$ followed by the exposure to different stimuli $\left(10 \mathrm{mM} \mathrm{CaCl}_{2}, 1 \mathrm{mM}\right.$ glutamate, and $1 \mu \mathrm{M}$ ionomycin) for at least? $1 \mathrm{~min}$. A mixture of D-luciferin and luciferase was added to each well to result in an equimolar concentration $(0.2 \mathrm{mg} / \mathrm{mL})$ of each. Luminescence measurements were acquired using a Synergy 4 Multi-Detection Microplate Reader (Biotek) at a wavelength of $590 \mathrm{~nm}$. All recordings were obtained at RT with a gain of 200, a read height of $2.00 \mathrm{~mm}$ and an integration time of $1 \mathrm{sec}$ per well.

\section{Supplementary Material}

Refer to Web version on PubMed Central for supplementary material.

\section{ACKNOWLEDGMENTS}

The authors would like to thank Mr. Danilo Masson de Souza for his contribution and assistance in tissue culture experiments. Funding Research reported in this publication was supported by the National Institute of General Medical Sciences of the National Institutes of Health under Award Number R01GM117159. The content is solely 
the responsibility of the authors and does not necessarily represent the official views of the National Institutes of Health.

\section{REFERENCES}

(1). Conditions P; Fiacco TA; Mccarthy KD; Savtchouk XI; Volterra XA Gliotransmission: Beyond Black-and-White. J. Neurosci 2018, 38, 14-25. [PubMed: 29298905]

(2). Fiacco XTA; Mccarthy KD Multiple Lines of Evidence Indicate That Gliotransmission Does Not Occur under Physiological Conditions. J. Neurosci 2018, 38 (1), 3-13. [PubMed: 29298904]

(3). Verderio C; Matteoli M ATP in Neuron-Glia Bidirectional Signalling. Brain Res. Rev 2011, 66, 106-114. [PubMed: 20451555]

(4). Franke H; Verkhratsky A; Burnstock G; Illes P Pathophysiology of Astroglial Purinergic Signalling. Purinergic Signal 2012, 8, 629-657. [PubMed: 22544529]

(5). Bodin P; Burnstock G Purinergic Signalling: ATP Release. Neurochem. Res 2001, 26, 959-969. [PubMed: 11699948]

(6). Rappold PM; Tieu K Astrocytes and Therapeutics for Parkinson's Disease. Neurotherapeutics 2010, 7, 413-423. [PubMed: 20880505]

(7). Burnstock G Historical Review: ATP as a Neurotransmitter. Trends Pharmacol. Sci 2006, 27, 166176. [PubMed: 16487603]

(8). Coco S; Calegari F; Pravettoni E; Pozzi D; Taverna E; Rosa P; Matteoli M; Verderio C Storage and Release of ATP from Astrocytes in Culture. J. Biol. Chem 2002, 278, 1354-1362. [PubMed: 12414798]

(9). Guthrie PB; Knappenberger J; Segal M; Bennett MVL; Charles AC; Kater SB ATP Released from Astrocytes Mediates Glial Calcium Waves. J. Neurosci 1999, 19, 520-528. [PubMed: 9880572]

(10). Chefer VI; Thompson AC; Zapata A; Shippenberg TS Overview of Brain Microdialysis. In Current Protocols in Neuroscience; 2009; pp 1-35.

(11). Bhattacharya A; Wang Q; Ao H; Shoblock JR; Lord B; Aluisio L; Fraser I; Nepomuceno D; Neff RA; Welty N; et al. Pharmacological Characterization of a Novel Centrally Permeable P2×7 Receptor Antagonist: JNJ-47965567. Br. J. Pharmacol 2013, 170, 624-640. [PubMed: 23889535]

(12). Pangršič T; Potokar M; Stenovec M; Kreft M; Fabbretti E; Nistri A; Pryazhnikov E; Khiroug L; Giniatullin R; Zorec R Exocytotic Release of ATP from Cultured Astrocytes. J. Biol. Chem 2007, 282, 28149-28758. [PubMed: 17664274]

(13). Dallérac G; Chever O; Rouach N How Do Astrocytes Shape Synaptic Transmission? Insights from Electrophysiology. Front. Cell. Neurosci 2013, 7, 159. [PubMed: 24101894]

(14). Huang Y; Sudibya HG; Fu D; Xue R; Dong X; Li LJ; Chen P Label-Free Detection of ATP Release from Living Astrocytes with High Temporal Resolution Using Carbon Nanotube Network. Biosens. Bioelectron 2009, 24, 2716-2720. [PubMed: 19135355]

(15). Ross AE; Venton BJ Sawhorse Waveform Voltammetry for Selective Detection of Adenosine, ATP, and Hydrogen Peroxide. Anal. Chem 2014, 86, 7486-7493. [PubMed: 25005825]

(16). Nguyen MD; Venton BJ Fast-Scan Cyclic Voltammetry for the Characterization of Rapid Adenosine Release. Comput. Struct. Biotechnol. J 2015, 13, 47-54. [PubMed: 26900429]

(17). Llaudet E; Hatz S; Droniou M; Dale N Microelectrode Biosensor for Real-Time Measurement of ATP in Biological Tissue. Anal. Chem 2005, 77, 3267-3273. [PubMed: 15889918]

(18). Dale N; Hatz S; Tian F; Llaudet E Listening to the Brain: Microelectrode Biosensors for Neurochemicals. Trends Biotechnol 2005, 23, 420-428. [PubMed: 15950302]

(19). Liu Y; Zhou Q; Revzin A An Aptasensor for Electrochemical Detection of Tumor Necrosis Factor in Human Blood. Analyst 2013, 138, 4321-4326. [PubMed: 23745180]

(20). Arroyo-Currás N; Dauphin-Ducharme P; Ortega G; Ploense KL; Kippin TE; Plaxco KW SubSecond-Resolved Molecular Measurements in the Living Body Using Chronoamperometrically Interrogated Aptamer-Based Sensors. ACS Sensors 2018, 3, 360-366. [PubMed: 29124939]

(21). Liu J; Davila Morris MD; Macazo FC; Schoukroun-Barnes LR; White RJ The Current and Future Role of Aptamers in Electroanalysis. J. Electrochem. Soc 2014, 161, 301-313. 
(22). Schoukroun-Barnes LR; Macazo FC; Gutierrez B; Lottermoser J; Liu J; White RJ Reagentless, Structure-Switching, Electrochemical Aptamer-Based Sensors. Annu. Rev. Anal. Chem 2016, 9, $163-181$.

(23). Xiao Y; Lubin AA; Heeger AJ; Plaxco KW Label-Free Electronic Detection of Thrombin in Blood Serum by Using an Aptamer-Based Sensor. Angew. Chem. Int. Ed 2005, 44, 5456-5459.

(24). White RJ; Rowe AA; Plaxco KW Re-Engineering Aptamers to Support Reagentless, SelfReporting Electrochemical Sensors. Analyst 2010, 135, 589-594. [PubMed: 20174715]

(25). Huizenga DE; Szostak JW A DNA Aptamer That Binds Adenosine and ATP. 656 Biochem 1995, 34, 656-665. [PubMed: 7819261]

(26). Farjami E; Campos R; Nielsen JS; Gothelf KV; Kjems J; Ferapontova EE RNA Aptamer-Based Electrochemical Biosensor for Selective and Label-Free Analysis of Dopamine. Anal. Chem 2013, 85, 121-128. [PubMed: 23210972]

(27). Álvarez-Martos I; Campos R; Ferapontova EE Surface State of the Dopamine RNA Aptamer Affects Specific Recognition and Binding of Dopamine by the Aptamer-Modified Electrodes. Analyst 2015, 140, 4089-4096. [PubMed: 25882962]

(28). Ferapontova EE; Olsen EM; Gothelf KV An RNA Aptamer-Based Electrochemical Biosensor for Detection of Theophylline in Serum An RNA Aptamer-Based Electrochemical Biosensor for Detection of Theophylline in Serum. J. Am. Chem. Soc 2008, 130, 1-4.

(29). Santos-Cancel M; Lazenby RA; White RJ Rapid Two-Millisecond Interrogation of Electrochemical, Aptamer-Based Sensor Response Using Intermittent Pulse Amperometry. ACS Sensors 2018, 3, 1203-1209. [PubMed: 29762016]

(30). Schoukroun-Barnes LR; Wagan S; White RJ Enhancing the Analytical Performance of Electrochemical RNA Aptamer-Based Sensors for Sensitive Detection of Aminoglycoside Antibiotics. Anal. Chem 2014, 86, 1131-1137. [PubMed: 24377296]

(31). Liu J, Wagan S Davila M, Taylor J, and White RJ Achieving Reproducible Performance of Electrochemical, Folding Aptamer-Based Sensors on Microelectrodes: Challenges and Prospects. Anal. Chem 2014, 86, 11417-11424. [PubMed: 25337781]

(32). Schoukroun-Barnes LR, Glaser E and White RJ Heterogeneous Electrochemical Aptamer-Based Sensor Surfaces for Controlled Sensor Response. Langmuir 2015, 31, 6563-6569. [PubMed: 26005758]

(33). White RJ; Plaxco KW Exploiting Binding-Induced Changes in Probe Flexibility for the Optimization of Electrochemical Biosensors. Anal. Chem 2010, 82, 73-76. [PubMed: 20000457]

(34). Huang KC; White RJ Random Walk on a Leash: A Simple Single-Molecule Diffusion Model for Surface-Tethered Redox Molecules with Flexible Linkers. J. Am. Chem. Soc 2013, 135, 1280812817. [PubMed: 23919821]

(35). Liu Y; Liu Y; Matharu Z; Rahimian A; Revzin A Detecting Multiple Cell-Secreted Cytokines from the Same Aptamer-Functionalized Electrode. Biosens. Bioelectron 2015, 64, 43-50. [PubMed: 25189099]

(36). Liu Y; Rahimian A; Krylyuk S; Vu T; Crulhas B; Stybayeva G; Imanbekova M; Shin DS; Davydov A; Revzin A Nanowire Aptasensors for Electrochemical Detection of Cell-Secreted Cytokines. ACS Sensors 2017, 2, 1644-1652. [PubMed: 28991491]

(37). Matharu Z; Patel D; Gao Y; Haque A; Zhou Q; Revzin A Detecting Transforming Growth Factor$\beta$ Release from Liver Cells Using an Aptasensor Integrated with Microfluidics. Anal. Chem 2014, 86, 8865-8872. [PubMed: 25105888]

(38). Schoukroun-barnes LR; Wagan S; Liu J; Leach JB; White RJ Biocompatible Hydrogel Membranes for the Protection of RNA Aptamer- Based Electrochemical Sensors. Proc. SPIE 2013, 8719, 13-16.

(39). Santos-Cancel M; White RJ Collagen Membranes with Ribonuclease Inhibitors for Long-Term Stability of Electrochemical Aptamer-Based Sensors Employing RNA. Anal. Chem 2017, 89, 5598-5604. [PubMed: 28440619]

(40). Balasubramanian S; Packard JA; Leach JB; Powell EM Three-Dimensional Environment Sustains Morphological Heterogeneity and Promotes Phenotypic Progression During Astrocyte Development. Tissue Eng. Part A 2016, 22, 885-898. [PubMed: 27193766] 
(41). Placone AL; McGuiggan PM; Bergles DE; Guerrero-Cazares H; Qui A; Searson PC Human Astrocytes Develop Physiological Morphology and Remain Quiescent in a Novel 3D Matrix. Biomaterials 2015, 42, 134-143. [PubMed: 25542801]

(42). Aregueta-Robles UA; Martens PJ; Poole-warren LA; Green RA Tissue Engineered Hydrogels Supporting 3D Neural Networks. Acta Biomater 2018, Article in Press, 1-16.

(43). Parenteau-Bareil R; Gauvin R; Berthod F Collagen-Based Biomaterials for Tissue Engineering Applications. Materials (Basel) 2010, 3, 1863-1887.

(44). Vermonden T; Censi R; Hennink WE Hydrogels for Protein Delivery. Chem. Rev 2011, 112, 2853-2888.

(45). An B; Lin Y-S; Brodsky B Collagen Interactions: Drug Design and Delivery. Adv. Drug Deliv. Rev 2015, 97, 69-84. [PubMed: 26631222]

(46). Baker B; Chen CS Deconstructing the Third Dimension - How 3D Culture Microenvironments Alter Cellular Cues. J. Cell Sci 2012, 125, 3015-3024. [PubMed: 22797912]

(47). Perea G; Araque A Glial Calcium Signaling and Neuron-Glia Communication. Cell Calcium 2005, 38, 375-382. [PubMed: 16105683]

(48). Li H; Arroyo-Currás N; Kang D; Ricci F; Plaxco KW Dual-Reporter Drift Correction To Enhance the Performance of Electrochemical Aptamer-Based Sensors in Whole Blood. J. Am. Chem. Soc 2016, 138, 15809-15812. [PubMed: 27960346]

(49). Araque Alfonso, Parpura Vladimir, S. RP and H. PG Tripartite Synapses: Glia, the Unacknowledged Partner. Trends Neurosci 1999, 22, 208-215. [PubMed: 10322493]

(50). Bal-Price A; Moneer Z; Brown GC Nitric Oxide Induces Rapid, Calcium- Dependent Release of Vesicular Glutamate and ATP From Cultured Rat Astrocytes. Glia 2002, 40, 312-323. [PubMed: 12420311]

(51). Cohen MS; Orth CB; Kim HJ; Jeon NL; Jaffrey SR Neurotrophin-Mediated Dendrite-to-Nucleus Signaling Revealed by Microfluidic Compartmentalization of Dendrites. Proc. Natl. Acad. Sci 2011, 108, 11246-11251. [PubMed: 21690335]

(52). Volterra A; Meldolesi J Astrocytes, From Brain Glue to Communicaiton Elements: The Revolution Continues. Nat. Rev. Neurosci 2005, 6, 626-640. [PubMed: 16025096]

(53). Morgan AJ; Jacob R Lonomycin Enhances Ca2 + Influx by Stimulating Store-Regulated Cation Entry and Not by a Direct Action at the Plasma Membrane. Biochem. J 1994, 672, 665-672.

(54). Araque A; Li N; Doyle RT; Haydon PG SNARE Protein-Dependent Glutamate Release from Astrocytes. J. Neurosci 2000, 20, 666-673. [PubMed: 10632596]

(55). Westerink RH; de Groot A; Vijverberg HP Heterogeneity of Catecholamine-Containing Vesicles in PC12 Cells. Biochem. Biophys. Res. Commun 2000, 270, 625-630. [PubMed: 10753674]

(56). Maekawa F; Pawlak R; Nagai N; Tsuboi T; Harada K; Kamiya T Gliotransmitter Release from Astrocytes: Functional, Developmental, and Pathological Implications in the Brain. Front. Neurosci 2016, 9, 1-9.

(57). Verkhratsky A; Burnstock G; Zimmermann H; Abbracchio MP Purinergic Signalling in the Nervous System: An Overview. Trends Neurosci 2009, 32, 19-29. [PubMed: 19008000]

(58). Butt AM ATP: A Ubiquitous Gliotransmitter Integrating Neuron-Glial Networks. Semin. Cell Dev. Biol 2011, 22, 205-213. [PubMed: 21376829]

(59). Zhang Z; Chen G; Zhou W; Song A; Xu T; Luo Q; Wang W; Gu X-S; Duan S Regulated ATP Release from Astrocytes through Lysosome Exocytosis. Nat. Cell Biol 2007, 9, 945-953. [PubMed: 17618272]

(60). Hwang DW; Jin Y; Lee DH; Kim HY; Cho HN; Chung HJ; Park Y; Youn H; Lee SJ; Lee HJ; et al. In Vivo Bioluminescence Imaging for Prolonged Survival of Transplanted Human Neural Stem Cells Using 3D Biocompatible Scaffold in Corticectomized Rat Model. PLoS One 2014, 9, $1-11$.

(61). Li Q; Wang Q; Wang O; Shao K; Lin H; Lei Y A Simple and Scalable Hydrogel-Based System for Culturing Protein-Producing Cells. PLoS One 2018, 13, 1-14.

(62). Westerink R; Ewing A The PC12 Cell as Model for Neurosecretion. Acta Physiol 2008, 192, 273-285. 
(63). Amatore C; Arbault S; Guille M; Lemaître F Electrochemical Monitoring of Single Cell Secretion: Vesicular Exocytosis and Oxidative Stress. Chem. Rev 2008, 108, 2585-2621. [PubMed: 18620370]

(64). Njus David, Kelley Patrick M., Harnadek GJ Quantum Dynamics in Classical Time Evolution of Correlation Functions. Biochim. Biophys. Acta 1986, 853, 237-239. [PubMed: 2887202]

(65). Pankratov Y Lalo Ulyana Verkhratsky Alexei North R. Alan, Vesicular Release of ATP at Central Synapses. Eur. J. Physiol 2006, 452, 589-597.

(66). Kasai Y; Ohta T; Nakazato Y; Ito S Release of Dopamine and ATP from PC12 Cells Treated with Dexamethasone, Reserpine and Bafilomycin A1. J. Vet. Med. Sci 2001, 63, 367-372. [PubMed: 11346169]

(67). Leach JB; Powell EM Neuromethods In Springe Protocols: Extracellular Matrix; Leach JB, Powell EM, Eds.; Springer: New York, 2015; pp 1-10. 

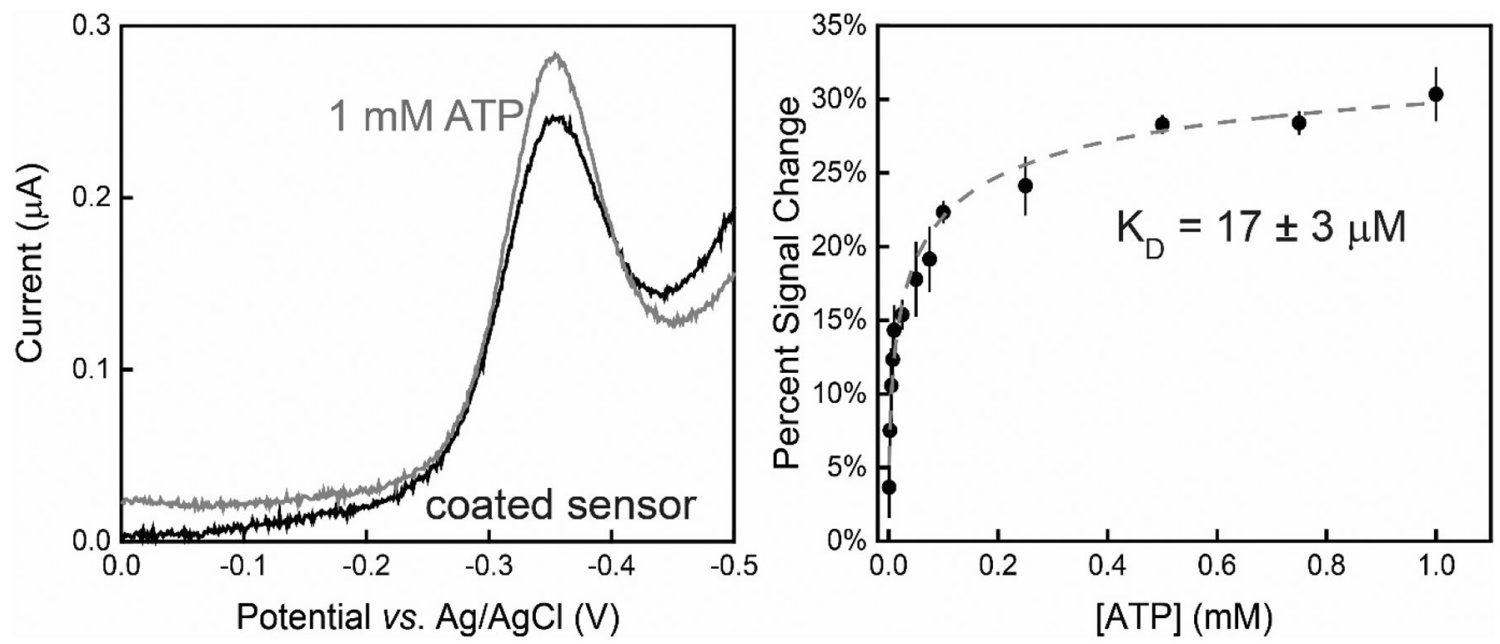

Figure 1.

Collagen-coated, structure-switching E-AB sensors specific to ATP exhibited a quantitative increase in faradaic current in the presence of ATP directly in cell culture media (84\% DMEM-high glucose, $15 \%$ FBS, and 1\% 10,000 U/mL Pen/Strep). (Left) Squarewave voltammograms exhibit an increase in peak current of $\sim 30 \%$ after the addition of $1 \mathrm{mM}$ ATP. (Right) The collagen-coated sensor exhibited an observed binding affinity $\left(K_{\mathrm{D}}\right)=17 \pm 3 \mu \mathrm{M}$ to ATP when the calibration curve was fit to a Langmuir-like isotherm. Data showed and error bars represent the mean and standard deviation of three independently fabricated $\mathrm{E}-\mathrm{AB}$ sensors using the same experimental conditions. 


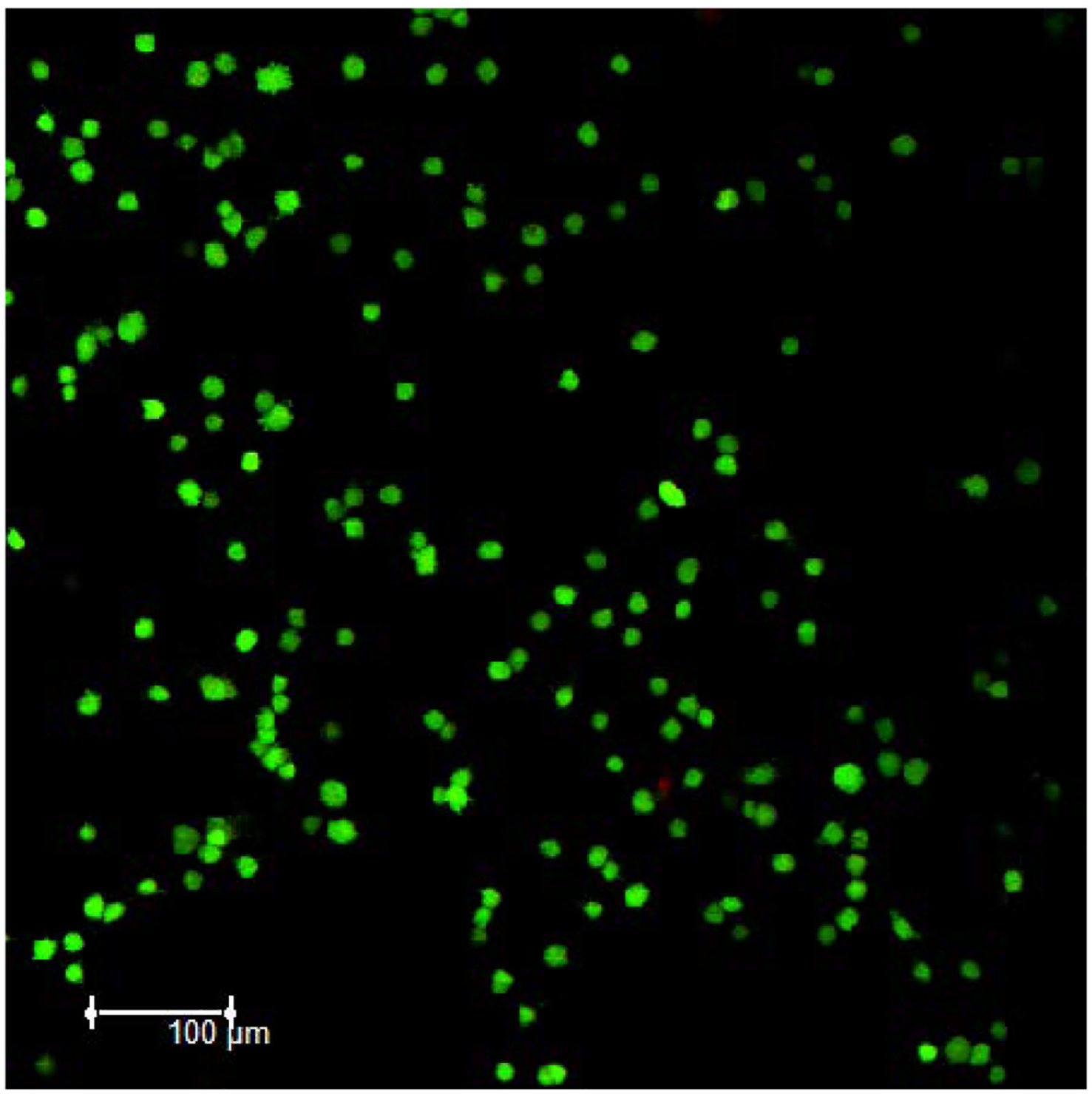

Figure 2.

Fluorescence images demonstrates $94 \%$ astrocyte viability (green fluorescent calcein AM dye) of an $8 \times 10^{5}$ astrocyte cell $/ \mathrm{mL}$ cell density encapsulated in a $0.8 \mathrm{mg} / \mathrm{mL}$ collagen I hydrogel when polymerized at RT for 30 mins and equilibrated in warm culture media for 1 hr. 

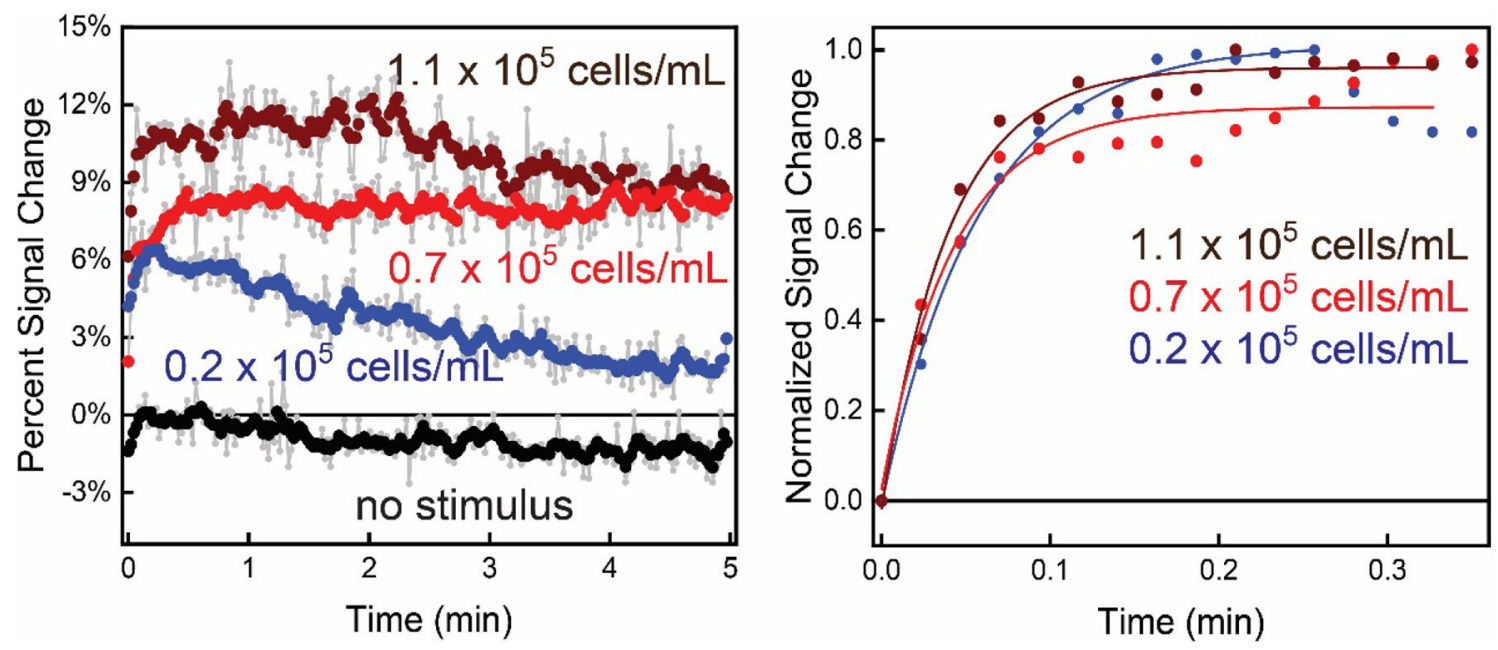

Figure 3.

The interface between E-AB sensors and 3D cell culture allows rapid (s) quantification of purinergic activity from astrocyte cells. (Left) More specifically, plotting the percent signal change in voltammetric peak current, we observe an increase in sensor signal upon $\mathrm{Ca}^{2+}$ evoked ATP release (at $t=0$ ) that is quantitatively related to the astrocyte population in the collagen hydrogel $\left(1.1,0.7\right.$, and $0.2 \times 10^{5}$ cells $/ \mathrm{mL}$ (wine, red, and blue, respectively)). The increase in signal is contrasted against a control signal when no $\mathrm{Ca}^{2+}$ is added. All raw data (light grey) was weight averaged to $n=5$ for ease of viewing. (Right) Normalized signal change of the E-AB sensor to ATP shows an exponential and rapid increase after the addition of stimulus. 

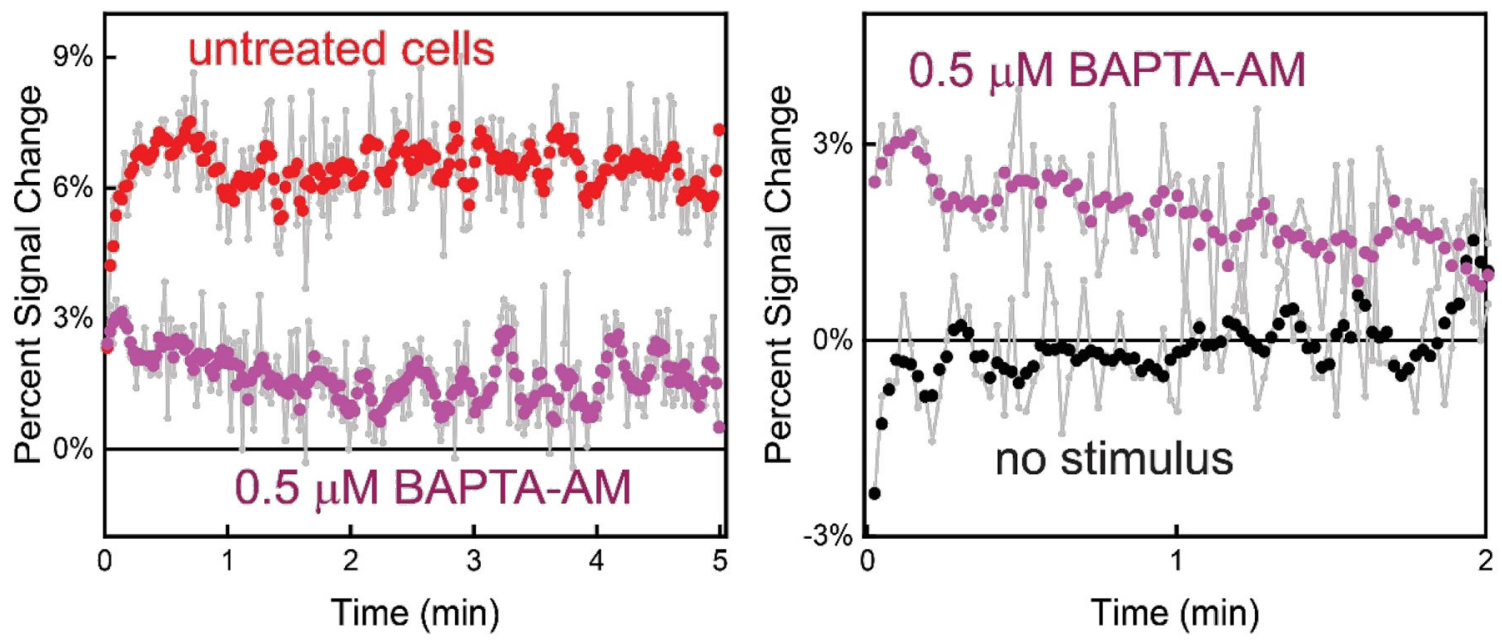

Figure 4.

Treatment with the $\left(\left[\mathrm{Ca}^{2+}\right]_{\mathrm{i}}\right)$ chelator BAPTA-AM significantly reduces extracellular ATP after stimulation with $\mathrm{Ca}^{2+}$ (at $t=0$ ) as indicated by a lower sensor signal change. (Left) For example, an untreated cell population density of $0.7 \times 10^{5}$ cells $/ \mathrm{mL}$ exhibits a signal increase of $\sim 7 \%$ with the addition of $\mathrm{Ca}^{2+}$ (untreated). Conversely, cells treated with BAPTA-AM only exhibited a $\sim 3 \%$ signal increase indicating a blocking of ATP release from astrocytes (treated). (Right) Treated cells, however, still released some ATP after evocation with $\mathrm{Ca}^{2+}$. Sensor signal increased $\sim 3 \%\left(\mathrm{Ca}^{2+}\right.$-triggered) compared signal without the addition of $\mathrm{Ca}^{2+}$. 

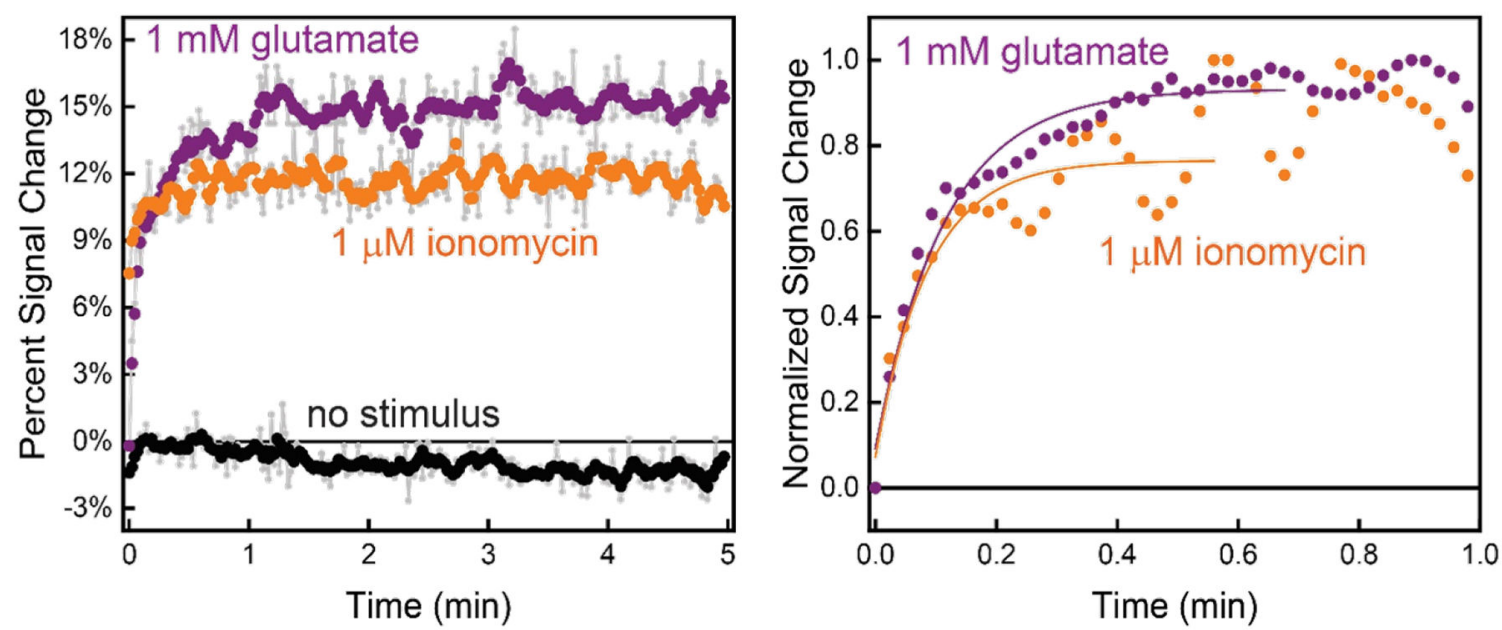

Figure 5.

Glutamate and ionomycin also stimulate ATP release from astrocytes. For example, the signal increase observed for glutamate, and ionomycin stimulation $(\mathrm{t}=0)$ are $\sim 14 \%$ and $\sim 12 \%$, respectively. This change in signal is contrasted to the lack of signal change observed without the addition of stimulus (as also shown in Figure 3). (Right) The incorporation of ionomycin to cell culture media results in a faster rise time in extracellular ATP compared to glutamate and $\mathrm{Ca}^{2+}$. All raw data (light grey) were adjacently averaged to $\mathrm{n}=5$. Individual experiments were carried out stimulating $0.7 \times 10^{5}$ astrocyte cells $/ \mathrm{mL}$ on top of individual E-AB sensors. 

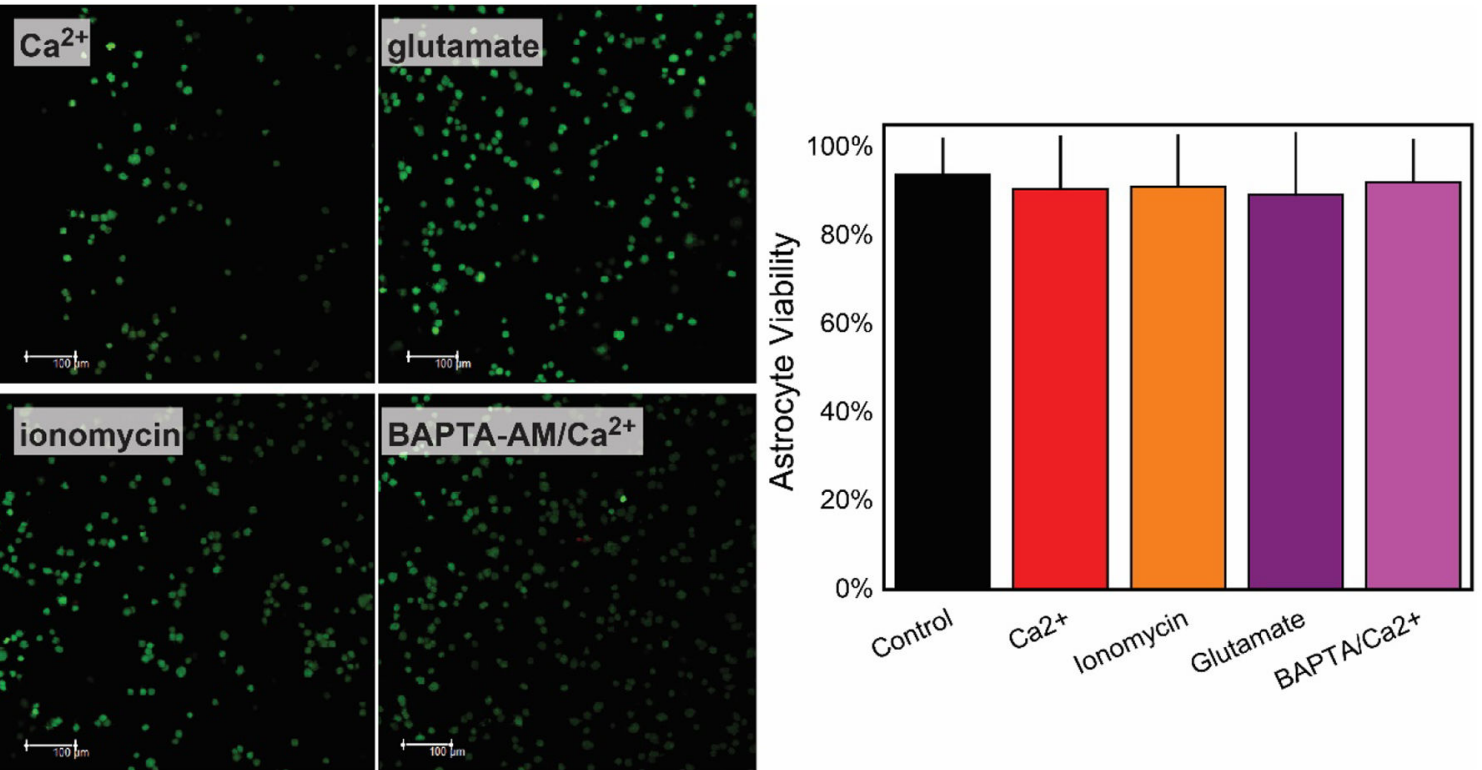

Figure 6.

Viability for an $8 \times 10^{5}$ cell $/ \mathrm{mL}$ cell density encapsulated in a $0.8 \mathrm{mg} / \mathrm{mL}$ collagen hydrogel remains minimally disturbed after chemical studies performed after the stimulation with 5 $\mathrm{mM} \mathrm{CaCl}_{2}, 1 \mathrm{mM}$ glutamate, $1 \mu \mathrm{M}$ ionomycin. Incorporation of BAPTA-AM did not cause detrimental effects, and cell remained viable after the incorporation of $\mathrm{Ca}^{2+}(\mathrm{Left})$. All images and viability test were acquired after the incubation (>1 min) with all triggers. Green and red fluorescent (viable and dead, respectively) images when acquired with a pvalue of 0.945 indicate there is no significant difference between the cell viabilities with stimulus and the control. 


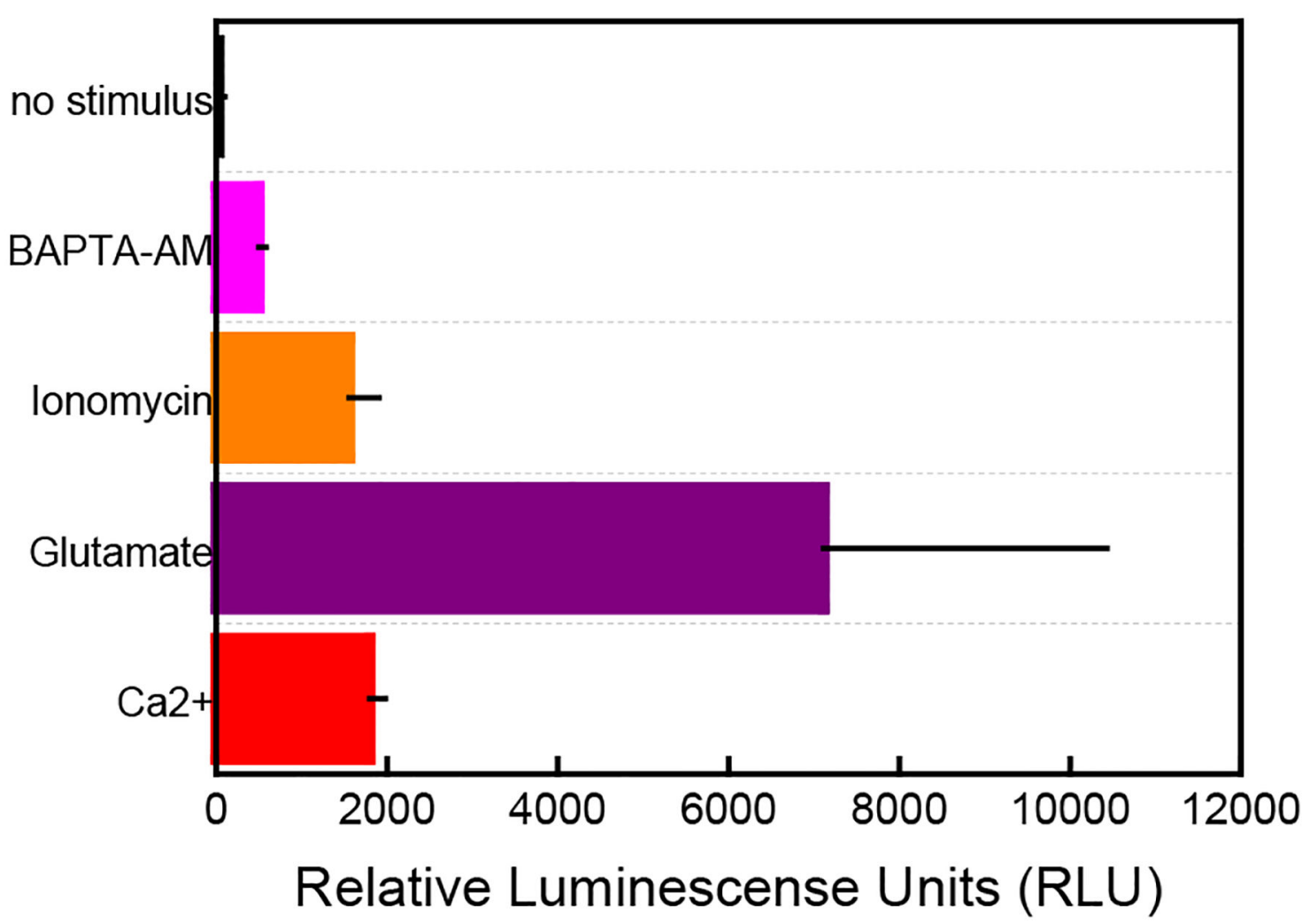

Figure 7.

Luciferin/luciferase bioluminescence assay confirms the presence of ATP in a $0.8 \mathrm{mg} / \mathrm{mL}$ collagen hydrogel after stimuli addition. Similar to the electrochemical recordings, the incorporation of glutamate induces the most substantial ATP response when compared with other stimuli (purple bar). The cells respond similarly when $\mathrm{Ca}^{2+}$ and ionomycin are added (red and orange bars, respectively). Treatment with the intracellular chelator, BAPTA-AM significantly reduces ATP signal when incubated for $1.5 \mathrm{hr}$ to the collagen-containing astrocytes (pink bar) and stimulated with $\mathrm{Ca}^{2+}$. The negative demonstrates that no ATP is released when no stimulus is added to a $0.7 \times 10^{5}$ cell $/ \mathrm{mL}$ density (black bar). All luminescence results were acquired and averaged $n=3$. 

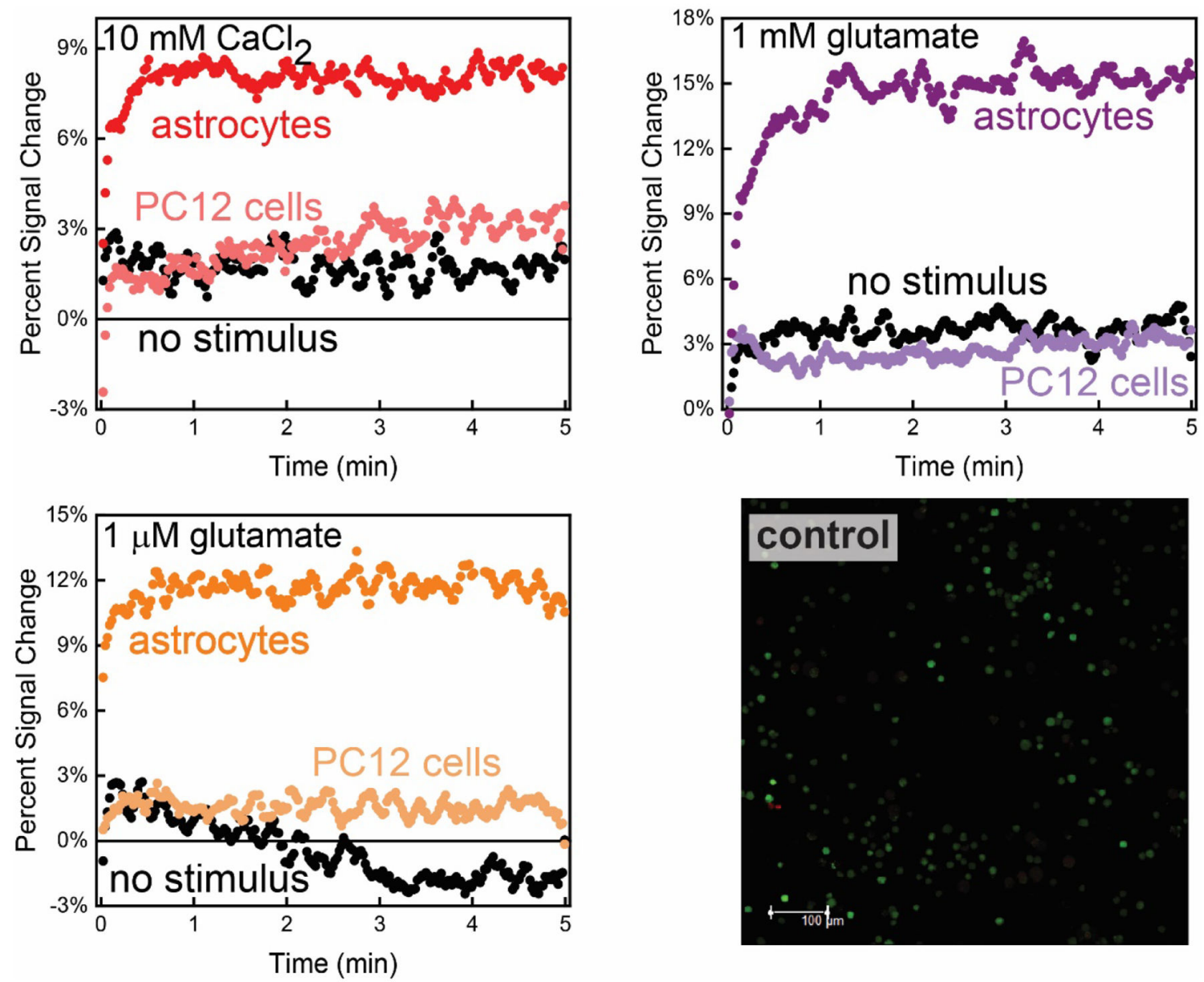

Figure 8.

The ATP E-AB sensor exhibited no appreciable response to catecholamine release from PC12 cells cultured in the sensor 3D cell culture array. (Top left) Stimulation with $\mathrm{Ca}^{2+}$ shows baseline sensor response (light red), comparable to electrochemical recordings when no stimulus is added to the cell culture media (black line trace). (Top right and bottom leftSimilarly, the sensor did not respond to catecholamine release upon the addition of glutamate and ionomycin (traces). comparison of the signal change generated by astrocytic $\mathrm{Ca}^{2+}$, glutamate and ionomycin-triggered ATP release (dark red, purple and orange time traces, respectively) confirms the specificity of the E-AB sensor to extracellular ATP presence after same stimuli were exerted in astrocytes cultured in same conditions. These figures encompass adjacent averaged $(n=5)$ raw data for the E-AB sensor response. (Bottom right) Control viability studies helped to visualize the stability of PC12 cells under current experimental conditions. Fluorescent images were acquired with a p-value of 0.183 indicating there is no significant difference between the cell viabilities with stimulus and the control. 

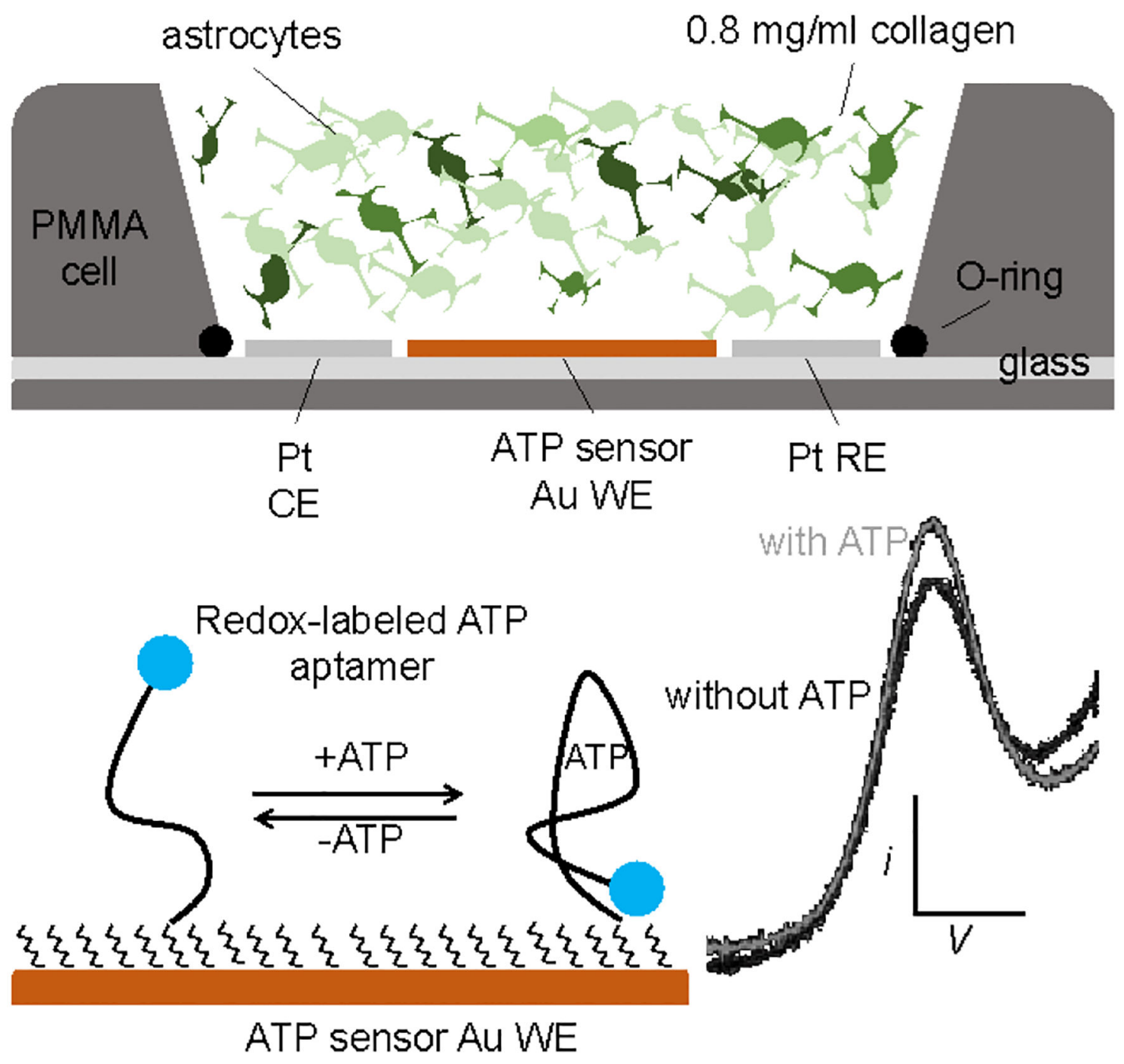

Scheme 1.

Crossectional representation of the E-AB sensor, 3D astrocyte cell culture hybrid interface. The three-electrode setup is placed inside a commercial holder (Micrux Technologies, Oviedo, Spain) with a PMMA holder on top where the 3D cell culture was polymerized, equilibrated, stimulated, and tested. Structure-switching E-AB sensors fabricated on the 1 $\mathrm{mm}$ working electrode allowed continuous quantification of ATP release from astrocytes. 